\title{
POLEMIK PENYIARAN PUBLIK DI INDONESIA: POTRET KONDISI TVRI
}

\author{
Arlan Firnandi \\ Dosen Prodi Ilmu Komunikasi, Universitas Putera Batam. \\ Email:kreptunis@gmail.com
}

\begin{abstract}
Public service broadcasting (PBS) has a central role in the terminology of the democratic broadcasting system. The role of PBS institutions is aspired to be an information balancing institution by bringing democratic values, plurality, and maintenance the cultural values of society. In Some Countries, Public broadcasting are not always in ideal conditions. Some Problems in internal and pressure from external are the factors that often hinder it. This article try to seeks the picture of condition of PBS in Indonesia, especially TVRI. The discussion is doing by tracing the history of birth and development, the problems present, and the challenges of the future that facing TVRI. This article uses a qualitative descriptive approach by using literature review method. The collecting of data doing by use literature review technique on relevant sources.
\end{abstract}

Keywords : Public Service Broadcasting, TVRI, Broadcasting Media System.

\section{PENDAHULUAN}

Penyiaran publik merupakan salah satu diantara empat bagian terminologi sistem penyiaran demokratis. Selain penyiaran publik, penyiaran swasta, berbayar, dan komunitas menjadi bagian dari terminologi ini. Setiap jenis penyiaran tentunya memiliki karakteristik tersendiri. Karakteristik ini tergambarkan jelas dalam program dan tujuan program. Termasuk tanggung jawab yang dibawa setiap lembaga.

Penyiaran publik memiliki karakter yang berbeda dengan 3 lembaga penyiaran lainnya. Penyiaran publik dikonsepkan sebagai lembaga penyiaran yang membawa cita-cita luhur. Lembaga ini secara khusus menjadi lembaga yang menempatkan kepentingan publik sebagai nilai yang utama. Oleh karena itu kepentingan ekonomi atau politik dilarang dalam penyiaran publik karena dikhawatirkan menenggelamkan kepentingan publik.

Dewasa ini penyiaran publik diharuskan menghadapi permasalahan yang begitu kompleks. Tekanan datang dari persaingan dengan penyiaran-penyiaran swasta, berbayar serta media-media multinasional. Meski perebutan ceruk pasar bukan menjadi tujuan penonton, namun jumlah penonton niscaya menjadi tolak ukur tingkat kebutuhan masyarakat. hal tersebut belum ditambah dengan persaingan dengan mediamedia baru, semisal portal berita online, dan media sosial.

Tulisan ini secara khusus akan menyisir hubungan TVRI dan rezim penguasa. Tulisan ini juga akan berusaha memetakan kondisi dan permasalahan terkini dari lembaga penyiaran publik yang ada di Indonesia, 


\section{Vol. 2 No.1 Agustus 2017}

khususnya TVRI. Selanjutnya pembahasan pada tulisan ini akan membahas tantangantantangan yang akan dihadapi TVRI dimasa yang akan datang. Artikel ini menggunakan metode telaah pustaka. Teknik Pengumpulan data dilakukan dengan melakukan penelusuran terhadap sumber-sumber terkait baik dari buku, jurnal, ilmiah dan artikel pemberitaan yang berhubungan dengan permasalahan.

\section{TINJAUAN PUSTAKA}

\section{Konsep Dasar Lembaga Penyiaran Publik} dan Kondisi di Beberapa Negara

Ide awal kehadiran dari public service broadcasting adalah berdasarkan pemikiran Jurgen Habermas, yaitu berakar pada kesatuan pengetahuan-pengetahuan publik dan pemahaman sebuah ruang publik, yang mana kehidupan sosial dan politik berkembang secara demokratis, dan sebisanya dalam tradisi independen. Kemudian, Public service broadcasting mengarah pada institusi yang dipandang ideal dari sebuah negara dalam memberikan pelayanan melalui penyiaran publik.

World Radio and Television Council ${ }^{1}$ memberikan gambaran bahwa pelayanan publik merupakan satu-satunya hal yang menjadi alasan dari eksistensi sebuah penyiaran publik. Mereka mengembangkan pengetahuan, dan membuat orang mampu

\footnotetext{
${ }^{1}$ World Radio And Television Council (2001): Public Broadcasting : Why? How ? pp. 7
}

mengerti lebih baik akan dirinya sendiri melalui pengertian yang lebih baik terhadap dunia dan orang lain.

Dalam dokumen tersebut penyiaran publik diartikan sebagai tempat pertemuan dimana semua warga disambut dan dianggap secara setara. Ia adalah alat informasi dan pendidikan, dapat diakses oleh semua orang, dan diperutukan untuk semua orang, apapun status ekonomi atau sosialnya. Mandatnya tidak terbatas pada perkembangan informasi dan budaya, penyiaran publik juga mendorong imajinasi dan menghibur, namun dibarengi dengan menampilkan kualitas yang membedakannya dengan penyiaran komersial.

Chris Hanretty ${ }^{2}$ menyebutkan bahwa definisi lembaga penyiaran publik kadang diartikan secara implisit hanya sebagai penyiaran yang hanya menawarkan konten layanan publik. Pandangan ini, bisa menjadi titik awal untuk melihat kriteria yang diperlukan untuk mengidentifikasikan penyiaran publik, namun hal ini tidaklah cukup. Lembaga penyiaran swasta juga bisa saja memberikan konten program untuk publik, karena merasa ada kewajiban untuk untuk melakukannya.

Oleh karena itu, Hanretty ${ }^{3}$ menawarkan definisi penyiaran publik dalam beberapa ciri khas, yaitu: (1) memiliki tujuan yang

\footnotetext{
${ }^{2}$ Hanretty, Chris (2011): Public Broadcasting and Political interference. New York: Routledge. h 4

${ }^{3}$ Ibid.
} 


\section{Vol. 2 No.1 Agustus 2017}

dinyatakan untuk menyediakan konten luas yang berguna secara sosial, (2) didanai oleh negara melalui pendapatan pajak umum atau melalui pajak tertentu (pajak siaran), (3) utamanya menyiarkan ke masyarakat di negara yang mendanainya, dan (4) berada di pos tertinggi dari penyiaran yang ditunjuk oleh badan negara.

McQuail $^{4}$ dalam tulisannya juga menyebutkan bahwa penyiaran publik merujuk pada sistem yang dibentuk oleh hukum dan umumnya dibiayai oleh dana publik (sering kali berupa iuran yang wajib dibayar oleh warga) dan diberikan keluasaan editorial dan kinerja yang mandiri. Alasan umum sistem semacam ini adalah mereka harus melayani kepentingan publik dengan memenuhi kebutuhan komunikasi yang penting bagi masyarakat dan warganya, sebagaimana ditentukan dan dinilai dengan cara sistem politik demokratis.

Penyiaran publik di beberapa negaranegara seperti di eropa, amerika, serta sedikit negara di asia memiliki beberapa kondisi dan permasalahan yang berbeda. Di eropa, televisi publik masih memiliki basis penonton yang baik. Salah satu contohnya adalah BBC di Inggris yang hingga saat ini masih memiliki basis penonton yang kuat. BBC bahkan saat ini tidak hanya bermain di dunia penyiaran, mereka bahkan melakukan perluasan dengan

\footnotetext{
${ }^{4}$ McQuail. Denis (2011): Teori Komunikasi Massa. Jakarta: Salemba Humanika. h. 196
}

membuka portal berita online. BBC versi online hingga saat ini memiliki 33 pilihan bahasa, termasuk versi bahasa Indonesia.

Perambahan BBC ke dunia berita online mengindikasikan bahwa adanya kesadaran dalam manajemen internal BBC dalam melihat kondisi masyarakat. Meski menambah fungsi ke versi online, BBC relatif tidak kehilangan karakternya sebagai media publik. Hal ini diindikasikan dari bersihnya laman-laman berita di portal berita BBC dari iklan. Frekuensi penerbitan beritanyapun tidak terlalu rapat. Hal ini keredaksian terbebani oleh target jumlah berita yang terbit tiap harinya. Sistem penerbitan yang tak terburuburu ini memberikan dampak positif karena memberikan jeda waktu untuk melakukan verifkasi data dan melakukan pendalaman berita.

Kondisi berbeda dialami penyiaran publik di Amerika Serikat. Menurut Monroe E. Price $^{5}$ dalam artikelnya yang berjudul Public Broadcasting And The Crisis Of Corporate Governance, disebutkan persentase penonton televisi publik di Amerika tidak setinggi di Eropa. Meski demikian, penduduk amerika masih memiliki kepedulian terhadap keberlangsungan televisi publik miliknya.

Demi memenuhi kebutuhan publik terhadap informasi, pemerintah Amerika

\footnotetext{
${ }^{5}$ Price, Monroe E. "Public Broadcasting And The Crisis Of Corporate Governance" Cardozo Arts \&Entertainment Vol. 17 h. 417 http://repository.upenn.edu/asc papers/119.
} 
Commed : Jurnal Komunikasi dan Media Vol. 2 No.1 Agustus 2017

Serikat bahkan memberlakukan peraturan agar penyiaran swasta dapat berlaku selayaknya lembaga penyiaran publik. Iswandi Syahputra ${ }^{6}$ mengatakan walau sudah diatur untuk kepentingan publik, namun industri televisi di Amerika yang bergerak dalam private sector (komersial) mendapat penolakan dari masyarakat yang tidak puas terhadap konten tayangan televisi publik. Hal ini menunjukkan bahwa akan sangat sulit untuk menyerahkan tanggung jawab penyiaran publik kepada kelompok swasta.

Graham Murdock dalam Burton ${ }^{7}$ menyebutkan ada empat peran kunci yang dilakukan oleh lembaga penyiaran publik dalam bentuknya yang klasik, diantaranya yaitu;

1. Menyediakan suatu forum publik bagi partai politik dan kelompok kepentingan yang sah.

2. Bertindak sebagai sumber pengawasaan dan umpan balik pihak berkuasa, hal ini berkenaan dengan dugaan-dugaan publik.

3. Membantu mempererat ikatan antara gagasan tentang kewarganegaraan dan definisi dominan tentang bangsa dan budaya.

\footnotetext{
${ }^{6}$ Syahputra, Iswandi. 2013. Rezim Media "pergulatan demokrasi, Jurnalisme dan Infotainment Dalam Industri Televisi”. Jakarta : PT Gramedia Pustaka Utama. hal. 154.

${ }^{7}$ Burton, Graeme. 2011. Membincangkan Televisi (terj. Laily Rahmawati). London : Hodder Arnold. hal. 70
}

ISSN. 2527-8673

4. Menarik kembali garis antara ruang publik dan ruang privat, yang membawa partisipasi dan peristiwa peristiwa publik ke dalam rumah.

Keadaan TVRI harus diakui dalam kondisi yang memprihatinkan. Beberapa hal yang menjadi permasalahan utama adalah keterbatasan sumber daya kreatif. Hal ini berkaitan dengan semakin besarnya jumlah pegawai dengan usia di atas usia produktif. Sebagian besar pegawai TVRI berstatus sebagai PNS. Hal ini sedikit banyak mempengaruhi pola kerja mereka yang sangat bersifat birokratis bukan berdasarkan inisatif atau kreatif. Permasalahan lain yaitu persaingan dengan televisi swasta, persentase penonton televisi publik yang rendah, serta intervensi dari unsur politik. Zianudin $\operatorname{Sardar}^{8}$ mengibarakatkan penyiaran publik layaknya seekor dinosaurus yang mencoba tetap eksis setelah meteor menghantam, maupun sebagai harapan terakhir yang paling baik untuk kebebasan berekspresi.

Dari segi sumber daya, televisi publik di Indonesia berbeda dengan televisi publik yang ada di Eropa dan Amerika. Untuk menutupi biaya opersional televisi publik di Eropa dan Amerika masih bisa mengandalkan iuran masyarakat. sedangkan Penyiaran publik di Indonesia saat ini nyaris hanya mengandalkan sokongan dari APBN.

\footnotetext{
${ }^{8}$ Sardar, Ziauddin. 2008. Membongkar Kuasa Media. Yogyakarta : Resist Book. hal. 126.
} 


\section{Vol. 2 No.1 Agustus 2017}

\section{PEMBAHASAN}

\section{Dari Asian Games Hingga Propaganda} Orde Baru

Berbicara mengenai TVRI tidak lengkap rasanya tanpa melihat latar sejarah lahirnya Televisi pertama di Indonesia ini. TVRI diresmikan pada tanggal 17 agustus 1962 pada saat peringatan Hari Kemerdekaan Republik Indonesia. TVRI merupakan proyek ambisius presiden Soekarno untuk menyokong penyelenggaraan Asian Games IV yang diadakan di Indonesia. TVRI dianggap menjadi proyek mercusuar pemerintahan Soekarno yang ingin menempatkan gengsi bangsa di mata dunia luar.

Pasca terjadi tragedi 30 September 1965 maka terjadi peralihan pemerintahan ke Presiden Soeharto, serta dimulailah babak baru TVRI. Pada pemerintah Soeharto TVRI menjadi Televisi Pemerintah Indonesia yang mendapatkan dana operasionalnya dari penghasilan iklan dan subsidi tahunan dari pemerintah. Sen dan Hill $^{9}$ dalam bukunya yang berjudul Media, Budaya dan Politik di Indonesia menyebutkan bahwa Pendapatan TVRI dari sektor iklan mengalami peningkatan yang sangat drastis. Dari 368 juta pada tahun 1971 menjadi 67,6 miliar pada tahun 1980. Tingginya jumlah pendapatan dari iklan pada masa itu dikarenakan belum adanya televisi-televisi lain sebagai pesaing. TVRI

\footnotetext{
${ }^{9}$ Sen, K and Hill, D. 2000. Media, Budaya dan Politik Di Indonesia. (terj. Sirkit Syah). United Kingdom, Victoria: Oxford University Press.
}

pada masa itu juga mendapat bantuan dari pemerintah, meskipun jumlahnya tidak sebanding dengan jumlah yang didapat dari sektor iklan. Pernah suatu waktu bantuan dari pemerintah ditingkatkan hingga 3 kali lipat, namun bantuan tersebut hanya menyumbang 1,4\% dari total pendapatan TVRI.

Terpusatnya pendapatan TVRI dari iklan mendapat kritik dari berbagai pihak terutama dari kelompok islam. Tingginya pendapatan dari iklan dianggap sebagai bentuk dukungan terhadap penyebaran budaya konsumtif. Hingga akhirnya pada 5 januari 1981, Presiden Soeharto menetapkan pemberhentian penerimaan TVRI dari sektor iklan. Langkah yang diambil Presiden Soeharto sekaligus menjadi rayuan terhadap kelompok islam. Hal ini dilakukan demi mendapat dukungan dari kelompok islam, karena adanya jarak antara kelompok islam dan pemerintahan Soeharto pada masa itu. Selanjutnya pemerintah saat itu meningkatkan hampir 10 kali bantuan tahunannya pada TVRI menjadi 10 miliar rupiah per tahun.

Dominannya sumber pendanaan dari pemerintah berdampak pada sistem pengelolaan TVRI. Dengan menguasai sumber keuangan membuat pemerintah orde baru memiliki kontrol terhadap struktur dan konten di TVRI. TVRI disulap menjadi televisi yang mengutamakan kepentingan pemerintah dalam menjaga kekuatan penguasa. Pemerintah tidak hanya menjadi pihak yang menentukan siapa 


\section{Vol. 2 No.1 Agustus 2017}

yang masuk ke dalam jajaran direksi, namun ikut mengontrol konten yang boleh tampil. Tayangan yang bersifat seremonial elit-elit pemerintahan dijadikan komodifikasi utama. Isu-isu lain seperti pelanggaran HAM dan lainlain yang banyak nyaris tak pernah diangkat.

Johan Galtung (dalam Siregar ${ }^{10}$ ) mengatakan bahwa pada konflik kepentingan tujuan-tujuan yang ditetapkan oleh orang luar sebagai kepentingan-kepentingan "sejati” dari kelompok-kelompok, dengan tiada menghiraukan seluruhnya atau sepenuhnya apa yang secara tegas dinyatakan oleh kelompokkelompok itu sendiri sebagai nilai-nilai yang mereka anut. Satu alasan untuk ini adalah penolakan dogma rasionalitas tak terbatas: para aktor tidak mesti mengetahui, atau mereka tidak dapat mengucapkan, apa kepentingan mereka. Alasan lain yang penting ialah bahwa rasionalitas tersebar tidak sama rata, sehingga yang satu bisa mendominasi jalan pikiran yang lain-lain, dan bahwa hal ini bisa menyebabkan "kesadaran palsu".

Kompleksitas Permasalahan Televisi Publik

Lepas dari rezim orde baru pada tahun 1998 sebenarnya menjadi momentum terbaik bagi TVRI untuk melepaskan diri dari ketergantungan dari pemerintah. Namun disisi lain kesempatan TVRI untuk menjadi media

10 Siregar, Amir E. 1991. Arus Pemikiran Ekonomi Politik. Yogyakarta : PT. Tiara Wicana Yogya. hal. 132133) yang profesional dan modern terkendala karena menjadi sasaran tembak dari berbagai pihak yang menganggap TVRI masih menjadi perpanjangan tangan dari rezim pemerintah orde baru. Publik sendiri masih tidak bisa lepas dari image TVRI dengan tayangantayangan Soeharto melakukan panen padi atau keberhasilan pemerintahan saat itu. Sehingga TVRI terus menerus ditinggalkan khalayak yang berpindah ke televisi lain yang dinilai lepas dari gambaran masa-masa kelam orde baru. Padahal televisi lainya seperti swasta sendiri tidak lepas dari kepentingan kapitalisme pemilik media komersial.

Jika melihat perkembangan TVRI sebagai televisi publik yang menjamin hak-hak atas informasi warga masyarakat yang statusnya bergerak. Semenjak berstatus Yayasan Gelora Bung Karno, Yayasan TVRI, Direktorat Televisi, Perusahaan Jawatan (Perjan) TVRI, PT TVRI (Persero), dan akhirnya Lembaga Penyiaran Publik (LPP) TVRI dianggap berbagai pihak sebagai titik tolak perubahan TVRI sebagai agen pembangunan dan penyeimbang penyampaian informasi di masyarakat. Bahkan pada peringatan ulang tahun TVRI ke 50, pemerintah melalui sambutan dari presiden SBY mengisyaratkan adanya harapan agar TVRI dapat merebut kembali perhatian dari penonton televisi di Indonesia dengan jalan meningkatkan kemampuan di segala lini, baik itu dari segi konten, sumber daya dan teknologi. 


\section{Vol. 2 No.1 Agustus 2017}

Tentunya banyak permasalahan yang dihadapi TVRI dalam menuju lembaga penyiaran publik yang ideal.

Televisi publik pada dasarnya tidaklah diharamkan untuk menerima pemasukan baik itu dari negara maupun dari iklan. Hal tersebut diperbolehkan selama pemasukan tersebut tidak mempengaruhi isi dari program yang ada di televisi publik. Dominasi dari negara seperti yang terjadi pada televisi publik di indonesia pada rezim Soeharto membuat TV publik seperti kehilangan tajinya untuk melakukan kontrol terhadap pemerintah demi memperjuangkan kepentingan publik.

Untuk itu penguatan penyiaran publik perlu ditopang dengan adanya penguatan kedudukannya dalam sebuah regulasi. Urgensi atas penguatan regulasi ruang dan kepentingan publik dalam regulasi media disebabkan oleh fungsi sosial publik sebagai pemegang kedaulatan yang utuh dan transparan. Ruang publik adalah tempat bagi setiap warga secara bebas terlibat dalam wacana realitas sosial yang mengontrol negara dan pasar. Fungsi media adalah untuk menjembatani dan menjadi wacana bebas bagi publik. Eka Wenats ${ }^{11}$ misalnya mengartikan ruang publik adalah tempat di mana ada ruang untuk media menyebarkan informasi fakta yang diperlukan untuk pemenuhan sikap baik sikap sosial, ekonomi, budaya maupun politik.

\footnotetext{
${ }^{11}$ Wenats, A.G, Eka, 2010. Regulasi, Globalisasi, dan Manajemen Media dalam Manjemen Media di Indonesia. Jakarta: Yayasan Pustaka Obor. hal 82.
}

Dilihat dari teori dari Jurgen Habermas tentang public sphere. Habermas menyebutkan bahwa sudah seharusnya tercipta forum yang terbuka sebagai arena penyampaian dan pembahasan permasalahan di masyarakat. Public sphere dicirikan sebagai sebuah forum yang menjunjung tinggi nilai demokrasi, pluraslisme dan lain-lain.

Permasalahan pertama yaitu adalah keterbatasan sumber daya keuangan yang dimiliki TVRI. Pada tahun 2007 TVRI sudah mengalami defisit anggaran. Meski mendapatkan kucuran dana sebesar 260 Miliar dari APBN TVRI masih mengalami kesulitan dalam pengelolaan anggaran. Pasalnya lebih dari 80 persen dari total anggaran tersebut harus tersedot untuk alokasi gaji pegawai. Jumlah pegawai TVRI pada tahun tersebut sudah mencapai 6.100 orang $^{12}$.

Pada tahun 2010 TVRI terjadi peningkatan jumlah pendanaan dari APBN. Pada tahun tersebut TVRI menerima kucuran dana sebesar 573 milyar rupiah. Namun jumlah tersebut hanya untuk menutupi 70 persen dana operasional. Pada pengajuan APBN tahun 2011 TVRI mengajukan kenaikan pendanaan hingga 1,3 triliun rupiah ${ }^{13}$. Beberapa pihak menilai pengajuan tersebut harus dibarengi dengan argumen berupa kinerja sebagai tolak ukur bagi pemerintah dan DPR.

\footnotetext{
${ }^{12}$ https://metro.tempo.co/read/98501/tvri-defisit-rp-50miliar. diakses pada 13 desember 2017

${ }_{13}$ https://www.ugm.ac.id/id/berita/2580kebijakan.finansial.masih.membebani.media.penyiaran. publik. Diakses pada 13 desember 2017
} 


\section{Vol. 2 No.1 Agustus 2017}

Pada tahun 2016 TVRI disebut-sebut menerima kucuran dana sebesar 1,6 triliun rupiah dari APBN. Tingginya alokasi dana yang digunakan untuk membiayai gaji karyawan membuat TVRI sulit berbicara banyak pada kualitas program. Pasalnya sejumlah dana tersebut harus digunakan untuk melakukan perawatan pada puluhan stasiun TVRI di pusat dan di daerah. TVRI harus membiayai 1 stasiun pusat dan 28 stasiun daerah.

Pada yang sama TVRI bahkan harus mendapat rapor merah dalam pemeriksaan Badan Pemeriksa Keuangan. BPK menyatakan opini Tidak Menyatakan Pendapat (TMP) atau disclaimer dari hasil pemeriksaan laporan TVRI. Meski bukan hanya TVRI yang mendapatkan opini tersebut, namun Presiden Jokowi menaruh perhatian besar pada lembaga ini. Pasalnya TVRI sudah mendapatkan disclaimer secara 4 tahun berturut-turut dan berpotensi merugikan negara sebesar hampir 400 Miliar rupiah ${ }^{14}$.

Permasalahan kedua yaitu mengenai kepercayaan publik. Menjadi sebuah tantangan bagi TVRI untuk berebut khalayak televisi dari dominasi televisi swasta. Di tengah upaya TVRI untuk memperbaiki konten-konten acara tentunya perlu adanya langkah persuasif agar khalayak juga kembali menonton tayangan TVRI. Pemilihan program yang lebih

\footnotetext{
${ }^{14}$ http://nasional.kompas.com/read/2016/10/05/1059313 1/presiden.beri.peringatan.kepada.tvri.yang.empat.kali.d apat.disclaimer.bpk. Diakses pada 13 desember 2017.
}

berkarakter dan berorientasi kepada kepentingan publik menjadi sebuah keharusan. Meski mencari bentuk program dalam kerangka kepentingan publik di Indonesia sulit karena kondisi Indonesia yang sangat plural.

Permasalahan ketiga yaitu belum adanya panduan yang memberikan gambaran secara jelas tentang karakter program untuk penyiaran publik. Dalam Peraturan Pemerintah nomor 13 tahun 2005 tentang Lembaga Penyiaran Publik Televisi Republik Indonesia sebetulnya telah diatur terkait kelembagaan TVRI. Peraturan tersebut berisikan peraturanperaturan terkait struktur dan mekanisme kelembagaan. Meski demikian Peraturan tersebut belum banyak menyentuh aspek pembuatan program. Hal yang seharusnya dimiliki dalam dunia kreatif seperti dunia penyiaran. Selain memberikan batasan yang jelas antara yang antara penyiaran publik dan swasta, hal ini akan membantu LPP dalam mengklasifikasi program yang akan diproduksinya. Beberapa kasus yang terjadi beberapa waktu lalu misalnya pada peliputan Muktamar Hizbut Tahrir pada Juni 2013 yang menyebabkan TVRI mendapat teguran dari $\mathrm{KPI}^{15}$. Hal ini menjadi salah satu indikasi bahwa masih adanya kebingungan dalam mengklasifikasi program dalam tubuh TVRI.

Pembentukan pedoman ini tentunya perlu untuk mempertimbangkan beberapa aspek,

\footnotetext{
${ }^{15}$ https://nasional.tempo.co/read/486551/siarkan-hizbuttahrir-tvri-dipanggil-kpi. Diakses pada 13 Desember 2017.
} 


\section{Vol. 2 No.1 Agustus 2017}

tidak hanya aspek yang bersifat internal, namun juga eksternal. Mempertimbangkan karakter dari sistem penyiaran di Indonesia menjadi sebuah keharusan dalam pembuatan regulasi. Sejarah, peta persaingan, dan perkembangan teknologi adalah beberapa hal yang menjadi aspek pertimbangan.

Eka Wenats ${ }^{16}$ menyebutkan dalam regulasi media harus dilihat sebagai satu keseluruhan permainan tiga aktor utama dari percaturan media massa terutama di Indonesia, yaitu pasar, masyarakat, dan negara. Hubungan antara tiga aktor utama itu tidak jarang bersifat mendua, artinya, di satu sisi hubungan yang baik adalah ketika ketiga aktor tersebut bisa menjalin hubungan yang harmonis dan saling mengisi. Tapi di sisi lain, hubungan antara ketiga aktor tersebut tersebut memungkinkan adanya pihak yang mendominasi pihak lain. Dalam kerangka pembuatan aturan main secara ekonomi politik fairness dalam bidang media. Maka dirasakan perlu untuk membentuk hubungan yang harmonis antara tiga aktor tersebut. Masalahnya institusi sah yang bisa mempunyai kekuasaan regulator adalah negara. Negara wajib dan berwenang untuk mengatur kebijakan media sehingga bisa mencapai fairness bagi semua pihak

Dalam kenyataannya kondisi fairness antara tiap aktor yang digambarkan seperti yang digambarkan di atas sulit untuk dicapai. Televisi komersial dalam kenyataannya tentu didominasi oleh kepentingan pasar. Rating acara menjadi prioritas utama untuk menarik iklan. Kondisi yang semakin diperparah karena di Indonesia hanya ada satu rating televisi yang dipakai. Padahal beberapa aspek lain perlu menjadi sebuah pertimbangan sehingga pasar tidak mendominasi dalam sistem penyiaran.

Ketika dominasi pasar terlalu kuat dalam sebuah sistem penyiaran, maka dampaknya juga akan ikut dirasakan penyiaran publik. Penyiaran publik akan sangat mungkin untuk ikut terbawa arus dominasi pasar dan tergeser dari bentuk idealnya. Pergeseran tersebut dikhawatirkan akan berdampak terhadap bentuk program acara, serta orientasi ideal lembaga.

Masih banyak masalah permasalahan yang mungkin secara lebih spesifik menjadi hal yang harus diperbaiki oleh TVRI dalam menjawab tantangan sebagai televisi yang menjadi andalan bangsa ini. Namun tiga hal di atas menjadi hal yang fundamental dan wajib diselesaikan oleh TVRI saat ini. Demi mencapai cita-cita dan harapan rakyat Indonesia atas pelayanan penyiaran publik yang menjadi pengendali keseimbangan informasi di tengah-tengah kehidupan masyarakat. 
Vol. 2 No.1 Agustus 2017

\section{Wacana Penggabungan (RTRI) dan}

\section{Digitalisasi}

Bimo Nugroho (dalam Agus Sudibyo ${ }^{17}$ ) menyebutkan setidaknya ada 3 prinsip dasar yang harus dan bisa dipertahankan oleh sebuah penyiaran publik yaitu prinsip kebebeasan berekspresi, prinsip frekuensi milik publik, dan prinsip demokrasi. Namun berpegang teguh pada 3 prinsip ini tidak lantas melepaskan TVRI dari belenggu permasalahan. Tentu masih banyak pembenahan yang harus dilakukan secara internal dan ekstenal.

Beberapa hal secara umum menggambarkan apa yang menjadi tantangan masa TVRI sebagai penyiaran publik. Berangkat dari hakikatnya TVRI seharusnya harus melepaskan diri aspek-aspek kepentingan oknum dan berangkat dengan niat untuk menyajikan tayangan yang mampu mencerdaskan serta mewakili seluruh kepentingan publik.

Pada tahun 2016 DPR RRI mencanangkan adanya peleburan TVRI dan RRI dalam sebuah wadah bernama RTRI atau Radio Televisi Republik Indonesia. Upaya peleburan ini dianggap sebagai bentuk penguatan pada posisi lembaga penyiaran publik di Indonesia. Selain itu efisiensi anggaran menjadi alasan

\footnotetext{
${ }^{17}$ Sudibyo, Agus. Andre, T. Aminuddin, Simbollah, N. 2004. Ekonomi Politik Media Penyiaran. Yogyakarta :
} LkiS Yogyakarta. hal.xvi-xvii. lain dari wacana ini. Pada tahun 2016, anggaran untuk kedua lembaga ini mencapai 2,6 triliun rupiah, 1,6 triliun untuk TVRI dan 1 triliun untuk RRI. Komisi DPR menilai bahwa jumlah tersebut dapat ditekan jika kedua lembaga tersebut berada dalam satu wadah. Hal yang perlu diperhatikan selain pertimbangan dari aspek keuangan adalah bahwa proses penggabungan ini harus menjamin nilai-nilai kepublikan.

Beberapa pihak menilai bahwa wacana ini memiliki beberapa tantangan. Pasalnya menggabungkan dua lembaga dengan dua kultur yang berbeda bukan hal yang mudah. Kebijakan penggabungan kedua lembaga publik bukan hal yang baru. RTM di Malaysia, RTP di Portugal, TRT di Turki merupakan beberapa contoh penggabungan dua lembaga penyiaran dalam satu wadah. Namun hal yang perlu menjadi catatan adalah bahwa Indonesia memiliki karakter yang berbeda karena sejarah yang berbeda antara RRI dan TVRI, sehingga proses penggabungan juga harus berbeda ${ }^{18}$

Setidaknya ada dua point krusial menjadi hal yang perlu diperhatikan sebelum penggabungan kedua lembaga ini dilakukan. Poin pertama yaitu terkait isu penetrasi dua lembaga yang perlu secara serius ditata sejak awal. Sejak awal perlu penekanan apakah dua lembaga ini akan digabungkan secara secara penuh atau secara parsial. Poin kedua yaitu

\footnotetext{
${ }^{18}$ Wahyuni, Hermin Indah. 2015. Presentasi

"Permasalahan LPP di Indonesia" Pada 8 April 2015 di Universitas Gadjah Mada Yogyakarta
} 


\section{Vol. 2 No.1 Agustus 2017}

adalah isu penataan mekanisme secara jelas menjadi hal yang sangat dibutuhkan untuk mengantisipasi permasalahan yang tak diharapkan di kemudian hari akibat adanya penggabungan ini. ${ }^{19}$

Tantang lainnya adalah adanya wacana digitalisasi dunia penyiaran di Indonesia.

kemampuan untuk bersiaran secara digital. TVRI sudah melakukan uji coba siaran digital pada 15 Juni $2016^{20}$.

Dalam sistem penyiaran terdapat dua jenis lembaga penyelenggara. Lembaga pertama disebut dengan lembaga penyiaran penyiaran program siaran (LPPS) dan lembaga penyiaran penyelenggara penyiaran multipleksing (LPPPM). LPPS merupakan lembaga yang menyediakan konten siaran. Sedangkan LPPPM menjadi induk yang memegang hak atas satu kanal penyiaran. Maka posisi LPPPM menjadi penting. Lembaga penyiaran yang memiliki status sebagai LPPPM akan memiliki hak untuk menentukan siapa saja yang bisa menyiarkan konten.

Banyak pihak menilai bahwa seharusnya TVRI menjadi salah satu lembaga yang memiliki yang nantinya harus memegang hak sebagai LPPPM. Hal ini guna menjamin terjaganya nilai diversity of content and diversity of ownership dalam sistem penyiaran di Indonesia. Hal ini akan membuat persaingan

\footnotetext{
${ }^{19}$ Ibid

${ }^{20}$ https://www.antaranews.com/berita/566334/uji-cobasiaran-tv-digital-15-juni. Diakses pada 13 Desember 2017
}

yang TVRI dengan televisi swasta akan semakin berat. Tarik menarik kepentingan tentu akan terjadi dalam arena ini.

Amir Effendi Siregar $^{21}$ pengamat penyiaran di Indonesia bahkan mengkhwatirkan teknologi digitalisasi ini akan

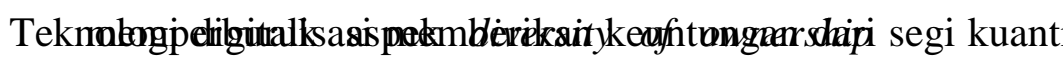
bahwa digitalisasi media penyiaran ini berpotensi menutup keragaman informasi kepada publik. Hal ini disebabkan ketentuan dalam peraturan itu membuka peluang pemain lama satu grup bisa menguasai lebih dari satu mux (penyedia kanal ke broadcaster) untuk beberapa program siaran yang diproduksi oleh grup tersebut.

Meski sempat dicanangkan akan dimulai pada awal tahun 2016, wacana digitalisasi ini akhirnya ditunda. Belum siapnya teknologi dan regulasi menjadi alasan utama penundaan digitalisasi. Meski ditunda, namun penerapan digitalisasi dipercaya sebagai sebuah keniscayaan dalam sistem penyiaran.

\section{KESIMPULAN}

Permasalahan yang terjadi di televisi publik di indonesia sebenarnya sebagian besar hampir sama dengan yang terjadi di televisi publik yang ada di seluruh dunia. Bagaimana penyiaran publik dapat terus bertahan ditengah-tengah persaingan dengan televisi komersil baik nasional maupun transnasional. Kehadiran televisi swasta dengan berkekuatan

21

http://tekno.kompas.com/read/2012/02/20/11115031/Di gitalisasi.Televisi. Diakses pada 13 Desember 2017 


\section{Vol. 2 No.1 Agustus 2017}

pendanaan kapitalis menjadi hal yang memperparah kondisi penyiaran publik.

Pengembangan TVRI juga seharusnya sudah melepaskan diri dari pengaruh-pengaruh politik elit yang ada di negeri ini. Seperti ungkapan Riant Nugroho ${ }^{22}$ dalam bukunya berjudul Public Policy mengatakan bahwa reinventing pembangunan sebagai paradigma pembangunan harus berubah dari paradigma politik ke paradigma manajemen. Pembangunan hingga hari ini lebih banyak dipahami sebagai momen politis dan historis dari pada momen manajemen.

Sumber pendanaan yang sebagian besar berasal dari APBN membuat TVRI sulit untuk mandiri. Aktor-aktor di dalam penyiaran publik harus terus jalan dengan ideologi kepentingan publik tanpa adanya kepentingankepentingan segelintir oknum dengan mengatasnamankan publik. Wacana terbaru separti penggabungan dengan RRI dan Digitalisasi juga menjadi sebuah perhatian dalam perkembangan LPP TVRI.

Tentu masih banyak pihak yang berharap TVRI sebagai lembaga penyiaran publik di indonesia dapat bangkit dan bersaing dengan televisi komersil baik dalam kualitas penyajian siaran maupun dalam hal persentase penonton. Beberarap LSM seperti MPM (Masyakakat Pemerhati Media), dan Remotivi menjadi salah dua lembaga yang lantang menyuarakan

\footnotetext{
${ }^{22}$ Nugroho, Riant. 2009. Public Policy. Jakarta: PT. Elex Media Komputindo. hal 643.
}

penguatan posisi TVRI sebagai televisi yang membawa keseimbangan dalam informasi. Dukungan-dukungan lain juga banyak mengalir dari kelompok akademisi, terutama akademisi dari bidang komunikasi. Penyiaran publik yang mandiri, lincah dan profesional memungkinkan tercapainya keseimbangan informasi yang disampaikan ke masyarakat.

\section{DAFTAR PUSTAKA}

Burton, Graeme. 2011. Membincangkan Televisi (terj. Laily Rahmawati). London : Hodder Arnold

Hanretty, Chris (2011): Public Broadcasting and Political interference. New York: Routledge.

McQuail. Denis (2011): Teori Komunikasi Massa. Jakarta: Salemba Humanika

Morissan. 2011. Manajemen Media Penyiaran : Strategi Mengelola Radio dan Televisi. Jakarta : Kencana

Mosco, Vincent. 1998. "The Political Economy of Communication". Great Britain, Trowbridge : Cromwell Press

Mufid, Muhammad. 2005. Komunikasi dan Regulasi Penyiaran. Jakarta: Kencana

Nugroho, Riant. 2009. Public Policy. Jakarta: PT. Elex Media Komputindo

Price, Monroe E. "Public Broadcasting And The Crisis of Corporate Governance" Cardozo Arts \&Entertainment Vol. 17 pp.417, http://repository.upenn.edu/asc papers/119. Diakses tanggal 1 April 2013

Sardar, Ziauddin. 2008. Membongkar Kuasa Media. Yogyakarta : Resist Book

Sen, K and Hill, D. 2000. Media, Budaya dan Politik Di Indonesia. (terj. Sirkit syah). United Kingdom, Victoria: Oxford University Press

Siregar, Amir E. 1991. Arus Pemikiran Ekonomi Politik. Yogyakarta : PT. Tiara Wicana Yogya

Sudibyo, Agus. Andre, T. Aminuddin, Simbollah, N. 2004. Ekonomi Politik 
Media Penyiaran. Yogyakarta : LkiS Yogyakarta

Syahputra , Iswandi. 2013. Rezim Media "Pergulatan Demokrasi, Jurnalisme dan Infotainment Dalam Industri Televisi". Jakarta : PT Gramedia Pustaka Utama

Wenats, A.G, Eka, 2010. Regulasi, Globalisasi, dan Manajemen Media dalam Manajemen Media di Indonesia. Jakarta: Yayasan Pustaka Obor

\section{Sumber Internet}

Antaranews.com. Uji Coba Siaran TV Digital 15 Juni.

https://www.antaranews.com/berita/566334/uji -coba-siaran-tv-digital-15-juni. Diakses pada 13 Desember 2017

Kompas.com. Amir Effendi Siregar.

Digitalisasi Televisi.

(http://tekno.kompas.com/read/2012/02/20/ 11115031/Digitalisasi.Televisi.) Diakses pada 13 Desember 2017.

Kompas.com. Presiden Beri Peringatan Kepada TVRI Yang Empat Kali Dapat Disclaimer BPK.

(http://nasional.kompas.com/read/2016/10/05/ 10593131/presiden.beri.peringatan.kepada. tvri.yang.empat.kali.dapat.disclaimer.bpk.

Diakses pada 13 desember 2017.

Tempo.co. TVRI Defisit Rp. 50 Miliar. (https://metro.tempo.co/read/98501/tvri-

defisit-rp-50-miliar) diakses pada 13 Desember 2017.

Website Universitas Gadjah Mada. Kebijakan Finansial Masih Membebani Media Penyiaran Publik

(https://www.ugm.ac.id/id/berita/2580kebijakan.finansial.masih.membebani.medi a.penyiaran.publik). Diakses pada 13 Desember 2017.

Tempo.co. Siarkan Hizbut Tahrir TVRI Dipanggil

KPIhttps://nasional.tempo.co/read/486551/ siarkan-hizbut-tahrir-tvri-dipanggil-kpi.

Diakses pada 13 Desember 2017.

\section{Sumber Lain}

Wahyuni, Hermin Indah. 2015. Presentasi "Permasalahan LPP di Indonesia" Pada Jambore Siaran Nasional RRI, 8 April
2015 di Universitas Gadjah Mada Yogyakarta. 